\title{
MUCIN HISTOCHEMISTRY OF TRACHEAL GOBLET CELLS AFTER ORAL ADMINISTRATION OF AMBROXOL
}

\author{
L. VAJNER ${ }^{1}$, V. KONRÁDOVÁ ${ }^{1}$, J. UHLÍK ${ }^{1}$, J. ZOCOVÁ ${ }^{2}$ \\ ${ }^{1}$ Institute of Histology and Embryology, $2^{\text {nd }}$ Medical Faculty, \\ ${ }^{2}$ Department of Applied Mathematics and Computer Science, Faculty of Science, \\ Charles University, Prague, Czech Republic
}

Received October 27, 2000

Accepted February 7, 2001

Abstract

Vajner L., V. Konrádová, J. Uhlík, J. Zocová: Mucin Histochemistry of Tracheal Goblet Cells after Oral Administration of Ambroxol. Acta Vet. Brno 2001, 70: 9-13.

Previous studies on the effect of various mucolytic drugs on the tracheal epithelium ultrastructure revealed ambroxol as the most harmful one. To complete these studies, we decided to evaluate the effect of ambroxol on the glycoconjugate content in the secretion of tracheal goblet cells.

Using the methods of both conventional and lectin histochemistry, the percentage of tracheal goblet cells containing various glycoconjugates was evaluated. Twenty minutes after oral administration of $7.5 \mathrm{mg}$ of ambroxol, goblet cells containing neutral glycoconjugates disappeared from the rabbit tracheal epithelium. Among goblet cells containing acidic glycoconjugates, the percentage of sialylated glycoconjugate-containing ones slightly decreased compared with control healthy rabbits.

Oral administration of ambroxol only slightly affected the composition of glycoconjugates contained in goblet cells of the tracheal epithelium in rabbits.

Tracheal goblet cells, conventional and lectin histochemistry, mucolytic drug ambroxol, rabbit

Ambroxol, the most frequently used mucolytic agent in clinical practice, affects both ciliated and secretory cells in the respiratory system. It stimulates ciliary activity as well as incorporation of precursors into phospholipids in granular pneumocytes causing thus a decrement of mucus adhesion to the hypophase. According to pharmacological studies, it facilitates incorporation of hydrolytic enzymes into lysosomes of the airways' secretory cells. Activation of these acidic mucopolysaccharide-degrading enzymes leads to a decrease of the sputum viscosity (Šmíd and Holcát 1994). In our previous studies, reactions of the rabbit tracheal epithelium to oral administration of a single therapeutic dose of 6 various mucolytic drugs were compared. The adverse effect of ambroxol was the most pronounced (Konrádová et al. 1985ab; 1996a). More than ninety seven per cent of the goblet cells had been stimulated to discharge their mucus. They either released their secretion from apical granules and/or detached packets of granules (14.5\%) or were completely evacuated $(83 \%)$ and only remnants of their degenerated cytoplasm were left in the epithelium. On the other hand, the cells of the rabbit terminal bronchiole revealed only mild signs of pathological alteration after oral administration of ambroxol and the secretory activity of Clara cells did not differ from that found in controls (Uhlík et al. in press).

Lamb and Reid (1972) and Damyanov (1987) deduced a common tendency to the decrease of sialylated glycoconjugates and the increase of sulphated ones as the reaction to any alteration of the tracheal epithelium.

To complete the study, changes of the glycoconjugate content of the tracheal goblet cells were studied under the same experimental conditions using both conventional and lectin histochemistry.

Address for correspondence:

MVDr. Luděk Vajner, CSc.

Charles University, $2^{\text {nd }}$ Medical Faculty

V úvalu 84, 15006 Praha 5 - Motol, Czech Republic
Phone: +420 224435982

Fax: +420224435820010

htt://ww vfuczlata-vet/actavethicz 


\section{Materials and Methods}

Seven SPF New Zealand White male rabbits (Charles River, Sulzfeld, Germany) of the average body weight $2219 \pm 484 \mathrm{~g}$ were used. Three of them were orally given $1 \mathrm{ml}$ of Mucosolvan sol. (Boehringer Ingelheim International $\mathrm{GmbH}$, Ingelheim, Germany), i.e. a dose routinely used in infants of the age up to one year. This volume contained $7.5 \mathrm{mg}$ of ambroxol (2-amino-3,5-dibromo-N-[trans-4 hydroxy cyclohexyl] benzylamine). The material was collected under general anaesthesia (ketamine $35 \mathrm{mg} / \mathrm{kg}$ and xylazine $5 \mathrm{mg} / \mathrm{kg}$ intramuscularly) and local subcutaneous infiltration of the ventral cervical field with procaine, 20 min post exposure. Four rabbits served as untreated healthy controls, the material was collected immediately after the induction of anaesthesia. The experimental procedures were approved by the Animals Protection Expert Commission of the Faculty.

The middle portions of tracheae between the $15^{\text {th }}$ and $20^{\text {th }}$ tracheal rings were sampled. The formalin-fixed samples were processed by the routine paraffin-embedding method. Serial sections 5-7 $\mu \mathrm{m}$ thick were made. The combined staining method of Alcian Blue at pH 2.5 (AB 2.5) followed by PAS-reaction according to Mowry and Winkler (1956) was used to reveal both total acidic and neutral glycoconjugates. Selective staining of acidic sulphated glycoconjugates was obtained using Alcian Blue at pH 1.0 (AB 1) (Kiernan 1981). Acidic nonsulphated (sialylated) glycoconjugates were counted as the difference between total acidic and acidic sulphated glycoconjugates. To detect sialylated glycoconjugates directly, the methods of in situ lectin histochemistry were used. At first, we used the Sata's modification (S at a et al. 1990) of digoxigenin-labelled lectin reaction, visualised by the alkaline phosphatase (AP)-X-phosphate (BCIP)-nitroblue tetrazolium (NBT) system (Boehringer Mannheim Biochemica, Germany). In this study, both Maackia amurensis agglutinin (MAA), detecting terminal $\mathrm{N}$-acetylneuraminic acid (2-3) glycosidically linked to galactose, and Sambucus nigra agglutinin (SNA), detecting terminal $\mathrm{N}$-acetylneuraminic acid $\alpha(2-6)$ glycosidically linked to galactose or $\mathrm{N}$-acetylgalactosamine, were employed. The Tritrichomonas mobilensis lectin (TML) (Calbiochem, La Jolla, USA) possessing the exclusive affinity to various modifications in linkages of both $\mathrm{N}$-acetylneuraminic and $\mathrm{N}$-glycolneuraminic acids was also employed (Babál et al. 1996). After dewaxing and rehydrating, the endogenous AP was blocked (Blocking reagent, Boehringer Mannheim Biochemica, Germany) and sections incubated with TML in the concentration 30 $\mu \mathrm{g} / \mathrm{ml}$ for $60 \mathrm{~min}$. The non-specific binding sites to the primary antibody were blocked by 10 -min submersion in $5 \%$ low-fat milk. Then the sections were incubated with the primary monoclonal antibody against TML (Calbiochem, La Jolla, USA) in the dilution 1:100 for $20 \mathrm{~min}$. As the last step, the secondary polyclonal rabbit antibody against the whole molecule of the mouse IgG, labelled with AP (Sigma-Aldrich Chemie, Deisenhofen, Germany) in the dilution 1:50 for 30 minutes, followed by BCIP-NBT visualisation, was used. Blocking endogenous AP was verified by omitting the first step of the method. Specific lectin binding was verified by $15-$ min incubation of lectins with control substrates - transferrin and fetuin - preceding the incubation with sections.

Only goblet cells containing well-developed granules with the positive reaction were evaluated. Marginal sections of the cells as well as differentiating or empty secretory elements were not included. The absolute numbers of evaluated goblet cells were 398 and 402 in control and treated animals, respectively.

For statistical evaluation, relative values of the six categories of goblet cells were evaluated by the chi-square test of homogeneity in frequency tables, using the Yates' correction in low frequencies when appropriate. The equivalency of sialylated glycoconjugate-detecting methods was tested by the paired $t$-test, median (sign) test, and Wilcoxon's paired test.

\section{Results}

The tracheae of both control and treated rabbits were lined with the pseudostratified columnar ciliated epithelium composed mostly of ciliated, goblet, and basal cells. The height of the epithelium was 25 to $30 \mu \mathrm{m}$. The distribution of secretory elements was irregular.

Using conventional histochemical methods, the secretory elements revealed typical staining patterns according to the type of glycoconjugates they contained.

The positive reaction of MAA was featured mostly with the intensive staining of the whole volume of mucous granules in a goblet cell. Sometimes, the mucous granules appeared as densely contrasted rings (Plate IV, Fig. 1). The ciliary border was always densely stained, too. TML reacted in a similar way as MAA. SNA-reaction depicted individual mucous granules as tiny rings, staining of the ciliary border was restricted to the close vicinity of apical surfaces of goblet cells.

In healthy control rabbits, we revealed $1.5 \pm 2.4 \%$ of goblet cells containing mucous granules with neutral glycoconjugates and $71.9 \pm 6.4 \%$ of goblet cells with acidic sulphated glycoconjugates (Fig. 3), respectively. We found $26.6 \pm 6.4 \%$ of the goblet cells containing acidic non-sulphated glycoconjugates. TML-positive sialylated glycoconjugates were found in $26.6 \pm 11.5 \%$ of goblet cells, MAA-positive ones in $27.9 \pm 8.4 \%$, SNA-positive 


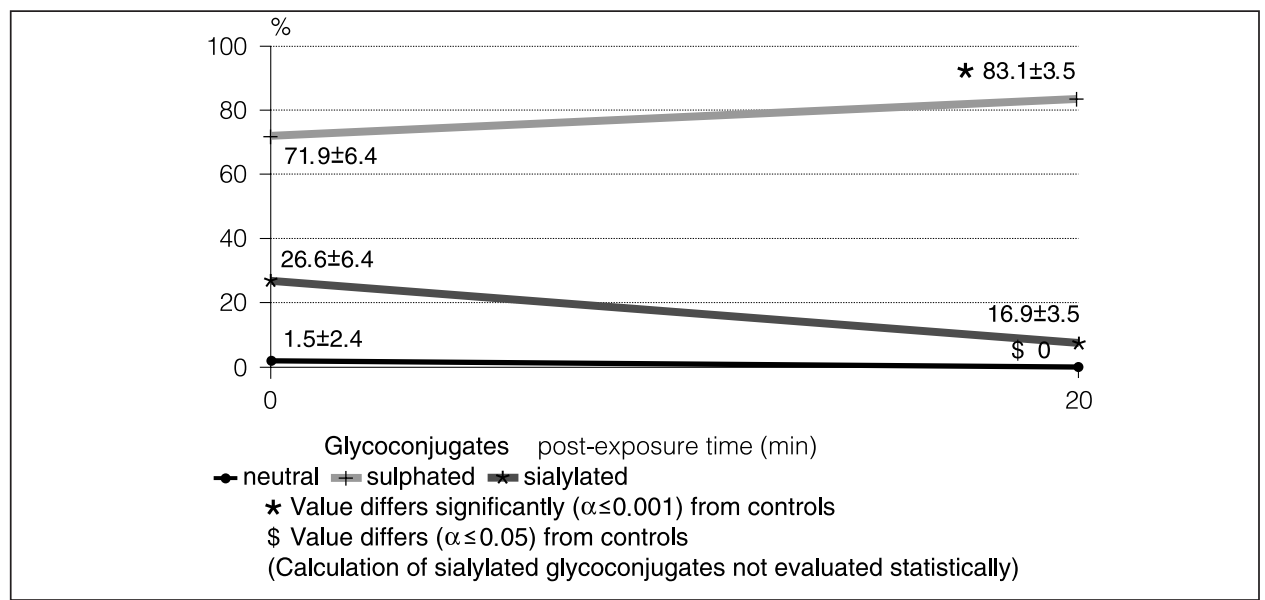

Fig. 3: Changes in percentage of tracheal goblet cells containing different glycoconjugates after ambroxol administration. Conventional histochemistry.

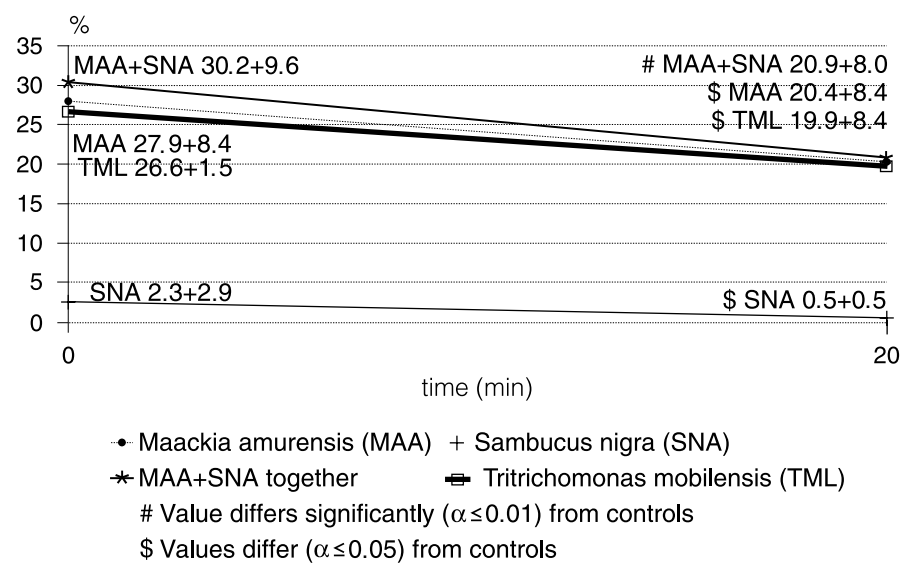

Fig. 4: Changes in percentage of tracheal goblet cells containing sialylated glycoconjugates after ambroxol administration. Lectin histochemistry.

glycoconjugates in $2.3 \pm 2.9 \%$, and both MAA- and SNA-positive glycoconjugates in 30.2 $\pm 9.6 \%$ of goblet cells (Fig. 4).

Twenty min after the administration of $7.5 \mathrm{mg}$ of ambroxol, no goblet cells containing neutral glycoconjugates were discovered. Goblet cells with acidic sulphated glycoconjugates represented $83.1 \pm 3.5 \%$ (Fig. 3). We counted the percentage of the goblet cells containing acidic non-sulphated glycoconjugates as $16.9 \pm 3.5 \%$. TML-positive sialylated glycoconjugates were found in $19.9 \pm 8.4 \%$ of goblet cells, MAA-positive ones in $20.4 \pm 8.4 \%$, SNA-positive glycoconjugates in $0.5 \pm 0.5 \%$, and both MAA- and SNApositive glycoconjugates in $20.9 \pm 8.0 \%$ of goblet cells (Plate IV, Fig. 4). Some goblet cells were found completely empty with only a narrow rim of cytoplasmic remnants (Fig. 2).

Statistical significance of differences between individual groups of goblet cells is shown in Figs 3 and 4. 


\section{Discussion}

As in our previous studies (Vajner 1998; Vajner et al. 2000), we found both neutral and acidic sulphated and acidic sialylated glycoconjugates in the mucous granules of goblet cells in the tracheal epithelium of the control rabbits. In experimental groups, we identified the same glycoconjugates. The exhausted goblet cells (Fig. 2) were not included in evaluation.

The data obtained by both conventional and lectin histochemistry were almost identical. The dynamics of changes in the percentage of MAA+SNA-positive goblet cells followed the same dynamics in TML-positive goblet cells. The percentage of goblet cells containing the glycoconjugates with the terminal $\alpha(2-6)$-linked $\mathrm{N}$-acetylneuraminic acid did not reach the zero point.

The change towards dominance of acidic sulphated glycoconjugates was in accordance with studies of many authors on the influence of some noxae affecting the terminal glycosylation (Lamb and Reid 1972; Jones and Reid 1978; Damjan ov 1987; Jeffery et al. 1992). This tendency was strongly confirmed in our previous papers (Vajner 1998; Vajner et al. 2000) as a result of administration of some bronchospasmolytic drugs or a high dose of acetylcholine. At the level of electron microscopy, Konrádová et al. (1996b, 1998) documented moderate to severe damage to tracheal goblet cells after administration of the same drugs.

Ultrastructural findings in the tracheal epithelium after the oral administration of ambroxol (Konrádová et al. 1985ab, 1996a) indicated the overstimulation of the majority of secretory elements resulting even in their degeneration as well. This finding matched with our findings of some exhausted goblet cells (Fig. 2). On the other hand, the proportion of the goblet cells containing acidic sulphated and acidic sialylated glycoconjugates was not changed conspicuously.

Based on our results, we arrived at the conclusion that the oral administration of ambroxol only slightly affected the composition of glycoconjugates contained in goblet cells of the tracheal epithelium in rabbits. Changes were evaluated as being on the verge of statistical significance. The apparent discrepancy between ultrastructural and histochemical evaluations could be explained by the rapid, almost complete but proportional release of the individual kinds of glycoconjugates into goblet cells secretion.

\section{Histochemické vyšetření hlenu pohárkových buněk trachey po perorálním podání ambroxolu}

Předchozí studie prokázaly význačný poškozující účinek ambroxolu na ultrastrukturu pohárkových buněk tracheálního epitelu. Proto jsme se rozhodli studovat účinek ambroxolu i na složení glykokonjugátů v sekretu tracheálních pohárkových buněk.

Dvacet minut po perorálním podání 7,5 mg ambroxolu došlo v tracheálním epitelu králíků k vymizení pohárkových buněk obsahujících neutrální glykokonjugáty. Mezi pohárkovými buňkami obsahujícími kyselé glykokonjugáty došlo ke snížení podílu elementů s obsahem sialovaných glykokonjugátů. Żádný ze sledovaných typů glykokonjugátů nevymizel úplně. Změny byly na hranici statistické významnosti. Perorální podání $1 \mathrm{ml}$ Mucosolvanu tedy změnilo podíl glykokonjugátů $\mathrm{v}$ sekretu pohárkových buněk králičího tracheálního epitelu jen lehce. Zdánlivý rozpor mezi nálezy ultrastrukturálními a histochemickými lze vysvětlit rychlým, ale proporcionálním uvolňováním jednotlivých typů glykokonjugátů do sekretu stimulovaných pohárkových buněk.

Acknowledgements

This work was supported by the Grant Agency of Charles University (Grant No 185/98) and the Czech Ministry of Education, Youth and Physical Training (Research Project $N^{\circ} 111300003$ ). 


\section{References}

BABÁL, P., GARDNER, W.A. 1996: Histochemical localization of sialylated glycoconjugates with Tritrichomonas mobilensis lectin (TLM). Histol. Histopathol. 11: 621-631.

DAMJANOV, I. 1987: Biology of disease. Lectin cytochemistry and histochemistry. Lab. Invest. 57: 5-20.

JEFFERY, P.K., GAILLARD, D., MORET, S. 1992: Human airway secretory cells during development and in mature airway epithelium. Eur. Respir. J. 5: 93-104.

JONES, R., REID, L. 1978: Secretory cells and their glycoproteins in health and disease. Brit. Med. Bull. 34: 9-16. KIERNAN, J.A. 1981: Histological and histochemical methods: Theory and practice. Pergamon Press, Oxford, 344 pp.

KONRÁDOVÁ, V., VÁVROVÁ, V., ŠULOVÁ, J. 1985a: Účinek perorální aplikace jedné terapeutické dávky různých mukolytik na ultrastrukturu epitelu trachey králíků. Stud. Pneumol. Phthiseol. Cechosl. 45: 31-39.

KONRÁDOVÁ, V., VÁVROVÁ, V., ŠULOVÁ, J. 1985b: Dependence of the reaction of the goblet cells in the rabbit tracheal epithelium on the oral dose of the mucolytic agent. Folia Morphol. 33: 344-350.

KONRÁDOVÁ, V., UHLÍK, J., ZAJÍCOVÁ, A., VAJNER, L., ZOCOVÁ, J. 1996a: Změny v oblasti řasinkového lemu epitelu dýchacích cest vyvolané perorální aplikací mukolytik. Čs. Pediat. 51: 70-75.

KONRÁDOVÁ, V., UHLÍK, J., VAJNER, L., ZOCOVÁ, J. 1996b: Reaction of the goblet cells to the cholinergic stimulation. Acta Vet. Brno 65: 175-180.

KONRÁDOVÁ, V., UHLÍK, J., VAJNER, L., ZOCOVÁ, J. 1998: The effect of two $\beta_{2}$ adrenergic agonists on the ultrastructure of the airway epithelium in rabbits. Vet. Med.-Czech 43: 187-192.

LAMB, D., REID, L. 1972: Acidic glycoproteins produced by the mucous cells of the bronchial submucosal glands in the fetus and child: A histochemical study. Brit. J. Dis. Chest 66: 248-253.

MOWRY, R.W., WINKLER, C.H. 1956: The coloration of acidic carbohydrates of bacteria and fungi in tissue sections with special reference to capsule of Cryptococcus neoformans, pneumococci, and staphylococci. Am. J. Pathol. 32: 628-629.

SATA, T., ZUBER, C., ROTH, J. 1990: Lectin-digoxigenin conjugates: A new hapten system for glycoconjugate cytochemistry. Histochemistry 94: 1-11.

ŠMÍD, M., HOLCÁT, M. 1994: Expektorancia a antitusika. In: KATZUNG, B.G.: Základní a klinická farmakologie. H\&H, Jinočany u Prahy, pp. 301-303.

UHLÍK, J., KONRÁDOVÁ, V., VAJNER, L., ZOCOVÁ, J.: The effect of a single oral administration of ambroxol on the ultrastructure of the epithelium of terminal bronchioles in rabbits. Sborník lékařský, in press.

VAJNER, L. 1998: Účinek dvou $\beta$, sympatomimetických bronchospasmolytik na podíl sialovaných a sulfonovaných glykokonjugátů v sekretu pohárkových buněk tracheálního epitelu. Čs. Patol. 34: 13-16.

VAJNER, L., UHLÍK, J., KONRÁDOVÁ, V., ZOCOVÁ, J. 2000: The effect of intravenously administered acetylcholine on the glycoconjugate composition in goblet cells of the tracheal epithelium in rabbits. Acta Vet. Brno 69: 17-23. 